\title{
CFD wt Allele
}

National Cancer Institute

\section{Source}

National Cancer Institute. CFD wt Allele. NCI Thesaurus. Code C84325.

Human CFD wild-type allele is located in the vicinity of 19p13.3 and is approximately $4 \mathrm{~kb}$ in length. This allele, which encodes complement factor D protein, is involved in the alternate complement pathway. 